\title{
Strategy for Implementing Operations to Handle the Crime of Narcotics
}

\author{
Arif Purnama Oktora ${ }^{a^{*}}$ Hilaire Tegnan ${ }^{\mathrm{b}}$ \\ a Faculty of Law, Universitas Indonesia, Jakarta, Indonesia \\ bLaw School, William \& Mary, Williamsburg, Virginia, United States \\ *Corresponding author: arifoktora2010@gmail.com
}

\section{ARTICLE INFO}

\section{Article history}

Received: June 1, 2021

Revised: August 20, 2021

Accepted: August 25, 2021

\section{Keywords}

Law Enforcement;

Management Strategy;

Narcotics Crime

\section{ABSTRACT}

Narcotics abuse is closely related to illicit trafficking as part of trans national organized crime. People become dependent so that the supply continues to increase. The relationship between dealers and victims is solidly bonded. It is difficult for victims to escape from dealer/s, even though victims are not frequently involved. This solid relationship between dealer/s and victim/s put the police in difficulty overcoming the crime. However, the West Jakarta Metro Police successfully manages to tackle that challenge. This research takes place in the West Jakarta Police Station. This article aims to explain the strategy for handling the $120 \mathrm{~kg}$ narcotics crimes by the West Jakarta Metro Police. The results of this study indicate that the attainment of the West Jakarta Metro Police depends on four things: (1) the pungent substance of the law on narcotics; (2) adequate law enforcement; (3) strategic programs in improving the competence of components of investigators; and (4) the existence of institution facilities and structures that support the case handling process.

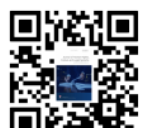

This is an open-access article under the CC-BY 4.0 license.

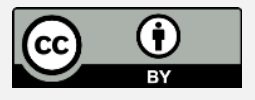

\section{Introduction}

Lately, the increasing number of narcotics trafficking and abuse cases in the community cannot be separated from the influencing factors, namely the demand factor, socializing in the nightlife environment, and the pressure factor from specific groups (factor) supply. ${ }^{1}$ In the distribution of narcotics, narcotics abusers are strongly influenced by the association in the community. The use and abuse of narcotics are often associated with environmental influences in society to live happily or have a fun, party and have fun because there is an assumption from users that when accompanied by narcotics, it is felt to be more fun regardless of the adverse effects caused. ${ }^{2}$

${ }^{1}$ Glen Hanson, Peter Venturelli, and Annette Fleckenstein, Drugs and Society (Burlington: Jones \& Bartlett Publishers, 2011). Google Scholar

${ }^{2}$ Michael D Lyman, Drugs in Society: Causes, Concepts, and Control, 7th edn (New York: Routledge, 2013). https://doi.org/https://doi.org/10.4324/9781315721682 
Narcotics abuse cases are closely related to illicit trafficking as part of the world of international crime. The illicit trade mafia supplies narcotics so that people become dependent so that the supply continues to increase. ${ }^{3}$ The relationship between dealers/ dealers and victims makes it difficult for victims to escape from dealers/ dealers, and it is not uncommon for victims to be involved in illicit trafficking due to their increasing need for and dependence on narcotics. The increase in the illicit trafficking of narcotics cannot be separated from transnational criminal organizations operating in various countries in an international crime network. Because of the enormous profits, these criminal organizations try by all means to maintain and continue to develop the illicit drug trafficking business by infiltrating, interfering, and undermining government structures, legitimate trade and financial businesses, and influential groups in society. ${ }^{4}$

In fact, law enforcement officers in the country have done a lot of law enforcement on narcotics crime cases. These actions are carried out until the judge reaches a final legal decision in court. In the last few decades, law enforcement officers have succeeded in arresting drug dealers and traffickers. The maximum legal sanction given is the death penalty. These sanctions do not seem to have a deterrent effect for other perpetrators who have not been caught. They are increasingly expanding the area of drug trafficking and distribution. The higher the action taken by law enforcement officers, the higher the abuse and crime of narcotics are carried out. ${ }^{5}$

There is a comprehensive approach to tackling crime and drug abuse, commonly known as harm minimization. This approach consists of three main aspects: controlling the supply of narcotics or referred to as supply control, suppressing demand for narcotics or demand reduction, and suppressing the impact of damage due to narcotics or harm reduction. This approach can work well if there is good cooperation between all relevant agencies and elements of society in combating the problem of narcotics crime, starting from the preemptive, preventive, repressive, or repressive stage, curative stage to the stage of recovery or rehabilitation of victims or victims of a drug addict. ${ }^{6}$

${ }^{3}$ Ralf Emmers, 'International Regime-Building in ASEAN: Cooperation Against the Illicit Trafficking and Abuse of Arugs', Contemporary Southeast Asia, 29.3 (2007), 506-25. Google Scholar

${ }^{4}$ Matthew S Jenner, 'International Drug Trafficking: A Global Problem with a Domestic Solution', Indiana Journal of Global Legal Studies, $18.2 \quad$ (2011), 901-27. https://doi.org/10.2979/indjglolegstu.18.2.901

${ }^{5}$ Leo Beletsky, Grace E Macalino, and Scott Burris, 'Attitudes of Police Officers towards Syringe Access, Occupational Needle-Sticks, and Drug Use: A Qualitative Study of One City Police Department in the United States', International Journal of Drug Policy, 16.4 (2005), 267-74. https://doi.org/10.1016/j.drugpo.2005.01.009

${ }^{6}$ David F Duncan and others, 'Harm Reduction: An Emerging New Paradigm for Drug Education', Journal of Drug Education, 24.4 (1994), 281-90. https://doi.org/10.2190/087G-B4ET-08JYT08Y; Adam R Winstock, Kim Wolff, and John Ramsey, 'Ecstasy Pill Testing: Harm Minimization Gone Too Far?', Addiction, 96.8 (2001), 1139-48. https://doi.org/10.1046/j.1360-0443.2001.96811397.x 
DKI Jakarta Province, as the center of the capital, becomes the primary target for narcotics traffickers - not to mention the West Jakarta area - in distributing narcotics to users in large enough quantities. ${ }^{7}$ In Figure 1.1 below is a map of locations prone to narcotics trafficking in the jurisdiction of the West Jakarta Metro Police, including:

Figure 1.1

Map of Areas Prone to Narcotics Circulation

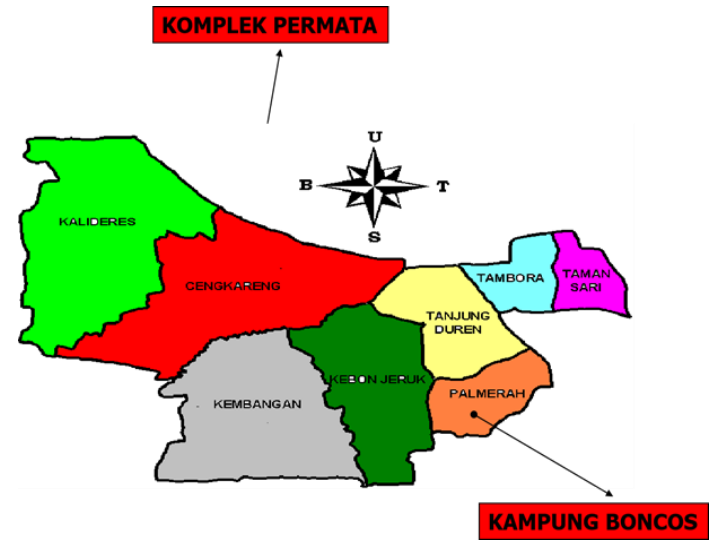

Source: West Jakarta Metro Police Narcotics Unit Data, 2020.

The map above depicts the area coverage of Kalideres, Cengkareng (Permata Complex/Ambon Village), Kembangan, Kebon Jeruk, Tanjung Duren, Palmerah (Boncos Village), Tambora, Taman Sari, all of which are under the jurisdiction of the West Jakarta Metro Police. Data from the West Jakarta Metro Police shows the total number of crimes (total crimes) related to narcotics from 2018 to November 2020 in 1062 cases. Meanwhile, the number of narcotics case settlements (crime clearance) reached 998 cases. The data is presented in the following table:

Table 1.1

Narcotics Case Recapitulation 2018 - 2020 West Jakarta Police

\begin{tabular}{|c|c|c|c|c|c|}
\hline \multirow[t]{2}{*}{ No } & \multirow[t]{2}{*}{ Details } & \multicolumn{3}{|c|}{ Years } & \multirow[t]{2}{*}{ Total } \\
\hline & & 2018 & 2019 & 2020 & \\
\hline 1 & Crime Total & 467 & 347 & 248 & 1062 \\
\hline & Crime Clearence & 409 & 367 & 222 & 998 \\
\hline & Suspects & 624 & 474 & 357 & 1455 \\
\hline & a. Men & 579 & 451 & 330 & 1360 \\
\hline & b. Women & 45 & 23 & 27 & 95 \\
\hline
\end{tabular}

7 Joko Adianto and others, 'From Shelters for Numbers to Shelters for Welfare: Rectifying the Social Housing Provision Programme in Jakarta', Housing Policy Debate, 2021, 1-19. https://doi.org/10.1080/10511482.2021.1981423 


\begin{tabular}{rllccc}
\hline a. & Ganja & 20 & 25 & 43 & $\mathbf{8 8}$ \\
\hline b. & Heroin & 0 & 0 & 0 & $\mathbf{0}$ \\
\hline c. & Shabu & 417 & 295 & 161 & $\mathbf{8 7 3}$ \\
\hline d. & Gorilla & 2 & 6 & 9 & $\mathbf{1 7}$ \\
\hline e. & Ecstasy & 25 & 11 & 25 & $\mathbf{6 1}$ \\
\hline f. & Pentilon & 1 & 1 & - & $\mathbf{2}$ \\
\hline g. & Kokain & 1 & 1 & 0 & $\mathbf{2}$
\end{tabular}

Source: West Jakarta Metro Police Narcotics Unit Data, 2021.

From table 1.2 above, it can be seen that narcotics crimes in 2018 were 467, while in 2019, there were 347, and in 2020 there were 248. The trend of narcotics crime at the West Jakarta Metro Police from 2018 to 2020 has decreased. Although the number has decreased, the role of drug dealers or dealers in prison remains large. They drive the sale and circulation of narcotics through accomplices outside the prison. This means that narcotics crimes are carried out by a network of highly organized and systematic groups, thus requiring the cooperation of all parties to participate in the success of law enforcement against narcotics crimes. ${ }^{8}$

One of the phenomenal narcotics crime cases in the West Jakarta Metro Police jurisdiction is the disclosure of the $120 \mathrm{~kg}$ smuggling case of methamphetaminetype narcotics carried out by the West Jakarta Metro Police 1 drug unit on April 15,2019 . The disclosure of the $120 \mathrm{~kg}$ case of methamphetamine received much positive appreciation, both from the community and the government, and even received an award from the Indonesian-World Record Museum (MURI) on Monday, May 20, 2019. (Quoted from https://megapolitan.kompas.com/read/2019/05/20/ 15243621/catch-1105-premandan-120-kg-sabu-sabu-polres-metro-jakbar-entered-record on April 18, 2021).

Chronology The case began when a drug transaction was ahead of the 2019 General Election. Hartono took $120 \mathrm{~kg}$ of crystal methamphetamine in Malaysia from Aseng. The methamphetamine contained in 5 sacks was then stored by Misri in Pekanbaru. Then Misri racked her brains to get $120 \mathrm{~kg}$ of crystal methamphetamine to reach Jakarta. Wisdom is also obtained. The methamphetamine package was inserted into a truck carrying 20 tons of charcoal. Misri's movement was detected by the West Jakarta Police team. On April 24, 2019, a green truck with Police Number B 9016 BEV driven by Jepi Candra was raided along with evidence of $120 \mathrm{~kg}$ of crystal methamphetamine. The case goes to court.

The disclosure of the $120 \mathrm{~kg}$ case of methamphetamine ensnared the suspect under Article 114 paragraph (2) Sub-Article 112 paragraph (2) Junto Article 132 paragraph (1) of Law No. 35 of 2009 concerning Narcotics, with the heaviest threat of capital punishment, life imprisonment, or imprisonment for a minimum of 5

\footnotetext{
${ }^{8}$ Fathurrohman and Gisela Bichler, 'Explaining the Positional Importance of Actors Involved in Trafficking Methamphetamine into Indonesia', Global Crime, 22.2 (2021), 93-122. https://doi.org/10.1080/17440572.2020.1819249
} 
(five) years and a maximum of 20 (twenty) years and a maximum fine as referred to in paragraph (1) plus $1 / 3$ (one third).

In the context of this type of methamphetamine narcotics crime, unprecedented amounts of methamphetamine weighing $120 \mathrm{~kg}$ have been found in the jurisdiction of the West Jakarta Police. Usually, the incoming methamphetamine weighs far below $120 \mathrm{~kg}$, even in size, ready to be distributed and marketed to users. In addition, the process of investigating the discovery of $120 \mathrm{~kg}$ of methamphetamine also requires careful and considerate strategic planning so that when the operation is carried out, it can minimize any possible failures.

\section{Research Method}

This research is descriptive qualitative. According to Sugiyono (2016: 9), qualitative research methods are used to examine the condition of natural objects where the researcher is the key instrument. To collect data, the techniques and methods used in this study consisted of interviews and document studies; 1. Interview 2. Document Study.

\section{Results and Discussion}

According to Stephanie, strategy is defined as a process of determining the plan of top leaders that focuses on the organization's long-term goals, accompanied by the preparation of a method or effort to achieve these goals. ${ }^{9}$ Jouch \& Glueck said that strategy is a unified, comprehensive, and integrated plan that links the advantages of organizational strategy with environmental challenges and is designed to ensure that the organization's main goals can be achieved through proper implementation by the organization. ${ }^{10}$

At the same time, the preparation of the strategy requires certain stages to be fulfilled. According to Triton (2007:17), six general stages need to be considered in formulating a strategy, namely, basic and critical selection of problems, stablish basic goals and strategic objectives, develop an action plan (action plan), develop an empowerment plan and onsidering advantages.

While the notion of strategic management is a series of basic and comprehensive decision-making activities accompanied by the determination of

9 Rebecca J Reichard and Stefanie K Johnson, 'Leader Self-Development as Organizational Strategy', The Leadership Quarterly, 22.1 (2011), 33-42. https://doi.org/10.1016/j.leaqua.2010.12.005

${ }^{10}$ Lawrence R Jauch, Richard N Osborn, and William F Glueck, 'Short Term Financial Success in Large Business Organizations: The Environment-Strategy Connection', Strategic Management Journal, 1.1 (1980), 49-63. https://doi.org/10.1002/smj.4250010106; Lawrence R Jauch, William F Glueck, and Richard N Osborn, 'Organizational Loyalty, Professional Commitment, and Academic Research Productivity', Academy of Management Journal, 21.1 (1978), 84-92. https:/doi.org/10.5465/255664; Lawrence R Jauch, Richard N Osborn, and William F Glueck, 'Success in Large Business Organizations: The Environment-Strategy Connection', in Academy of Management Proceedings (Academy of Management Briarcliff Manor, NY 10510, 1977), MCMLXXVII, 113-17. https://doi.org/10.5465/ambpp.1977.4977072 
how to implement them, they are made by top management and implemented by all levels within an organization to achieve its goals (Akdon, 2006:8). According to Nawawi (2005:149), strategic management is the flow of decisions and actions that lead to the development of a strategy or effective strategies to help achieve organizational goals. This understanding emphasizes that the flow of decisions from organizational leaders and actions in the form of implementing decisions must produce one or more strategies by choosing the most effective or reliable in achieving organizational goals.

Jouch \& Glueck strategic management is a number of decisions and actions that lead to the development of a strategy or a number of effective strategies to help achieve organizational goals. The strategic management is the art and science of formulating, implementing, and evaluating strategic decisions between functions that enable an organization to achieve future goals. ${ }^{11}$ According to J. David Hunger Strategic Management can be defined as the art and science of formulating, implementing, and evaluating cross-functional decisions that enable the organization to achieve its objectives. As this definition implies, strategic management focuses on integrating management, marketing, finance/accounting, productions/operations-research and development, computer information system to achieve organizational objectives. This definition shows that the important aspects of strategic management are Strategy Formulation, Strategy Implementation, and Strategy Evaluation. From the understanding of Strategic Management above, according to Wheelen and Hunger, ${ }^{12}$ there are four principles of strategic management.

Firstly, environment scanning, in this process, each problem encountered is identified in detail. This process is a very decisive process related to the problems faced. If the identification of the problem at this stage is not made carefully, it will affect the next stage. In addition to identifying problems, external opportunities and threats are also identified, measuring and determining internal strengths and weaknesses, setting long-term goals, collecting alternatives, and selecting specific strategies that will be applied to certain problems. Secondly, strategy formulation. Strategy formulation is closely related to the organization's main functions, which are clearly stated in the organization's mission statement. Specifically, according to LAN, the things that must be considered in formulating strategies (Akdon, 2006:82): (a) determine the vision, mission, goals, and objectives to be achieved

11 Farid Ahamd Monib and others, 'Comparative Study of Strategic Management Schools (Prescriptive, Descriptive and Integrated)', Open Journal of Business and Management, 9.4 (2021), 1965-79. https://doi.org/10.4236/ojbm.2021.94106; Martin Dandira, 'Involvement of Implementers: Missing Element in Strategy Formulation', Business Strategy Series, 12.1 (2011), 30-34. https://doi.org/10.1108/17515631111100386; Alan W Steiss, Strategic Management for Public and Nonprofit Organizations, ed. by Alan W. Steiss, 1st edn (New York: Routledge, 2019). https://doi.org/10.4324/9781482275865

12Thomas L Wheelen and others, Strategic Management and Business Policy, 14th edn (Pearson Boston, MA, 2017), LV. Google Scholar 
appropriately so that the final goals of the organization are achieved; (b) recognize the environment in which the organization is located; (c) conduct analysis to maintain existence and implement organizational goals. Thirdly, A strategy that describes how to achieve a goal. The performance plan is a benchmark used in assessing the success/failure of the organization within a certain period. (a) targets, performance indicators, and targets to be achieved in the period concerned; (b) programs to be implemented; (a) activities, performance indicators, and targets expected in an activity.

It is strategies that can measure, evaluate, and provide feedback on organizational performance. Performance measurement is a crucial stage to see and evaluate the achievements or results of the work's target. Performance measurement includes: (a) measurement, analysis, and evaluation of performance (level of achievement of targets/targets of each target indicator that has been set; (b) reporting and accountability. Strategy implementation is key for today's organizations. There are many soft and complex factors that affect the success of strategy implementation.

These factors include, among others, the person who communicates or implements the strategy on the existing system or mechanism for the coordination and supervision function. Research conducted by Yang Li et al. (2008) ${ }^{13}$ analyzes several factors that influence the strategy implementation process to discuss agreement and disagreement and something that needs to be done for future research. The definition of implementation can be interpreted as "execution" or "executing" in the context of strategy. However, from 60 pieces of works of literature, the term "strategy implementation" is used as a keyword. ${ }^{14}$ The strategy implementation tasks are the most complex and require far more time than the strategic management section. Therefore, some literature reviews do not distinguish between strategy implementation and execution. ${ }^{15}$

The behavior of enforcing the law and the behavior of using the law are two things that are difficult to distinguish because the two things complement each other. ${ }^{16}$ Therefore, carrying out law enforcement without using the law will give birth to arbitrariness (abus de droit). On the other hand, using the law without the intention to enforce the law will also lead to legal injustice or lawlessness. This paradox will be felt and experienced by law enforcement officers and other related parties such as police, prosecutors, judges, advocates, bureaucrats, politicians, and other parties involved in law enforcement. They will constantly be challenged to balance these two main things, namely enforcing the law and using the law

${ }_{13}$ Yang Li, Sun Guohui, and Martin J Eppler, Making Strategy Work: A Literature Review on the Factors Influencing Strategy Implementation (Beijing: Università della Svizzera italiana, 2008).

Google Scholar

${ }^{14} \mathrm{Li}$, Guohui, and Eppler. Google Scholar

${ }^{15} \mathrm{Li}$, Guohui, and Eppler. Google Scholar

16 Ronny Nitibaskara, Tegakkan Hukum Gunakan Hukum, ed. by Chris Verdyansah, 2nd edn (Jakarta: Penerbit Buku Kompas, 2007). Google Scholar 
simultaneously and in balance. Meanwhile, according to Soekanto, law enforcement is an activity to harmonize the relationship of values described in solid rules and attitudes of action as a series of final stages of value elaboration to create, maintain and maintain a peaceful social life. ${ }^{17}$ Among the various forms of crime that occurred, one type of crime was carried out in a neat, patterned, and organized manner by the group.

Generally, this type of crime is a business activity to reap large profits. The general term for this type of crime is organized crime in English. Siegel (2000) defines organized crime as a business activity by a group of criminals that is carried out in a sustainable manner in order to reap massive economic profits unilaterally through illegal and unlawful means. ${ }^{18}$ The existence of the group organization, especially the structure and system in it, was created to provide services to consumers of goods or services that are prohibited by the applicable criminal law. The existing system in organized crime is similar to the existing system in various legal and legitimate forms of business, which is led by an ambitious executive, assisted by assistants, legal advisors, professional accountants, and supported by the complaints department. ${ }^{19}$ Attempting to define organized crime is not an easy one. The English term organized crime does not merely mean organized crime. The phrase 'organized' does not yet reflect the sustainable business activity. Even the task force for Organized Crime in the United States has difficulty defining organized crime legally.

The results of research conducted by the United States Organized Crime Task Force found that the simplest definition of organized crime is the one used by the State of Mississippi when two or more people commit a conspiracy to commit a crime on an ongoing basis for profit jointly. A more complex definition is the one used by the State of California, namely when two or more people are involved in one or more acts, including (1) supplying unlawful goods and services such as prostitution, (2) very serious crimes, harm other people or society such as stealing, attacking, and others. With that definition, several crimes fall into the category of organized crime. Regarding law enforcement efforts, there is another choice of definition of organized crime because it is considered quite practical. There must be at least one position that is specifically meant to conduct the crime, as well as one that accepts and enforces bribes in the division of labor, which includes at least one post where bribery is accepted and another where it is enforced..$^{20}$

\footnotetext{
${ }^{17}$ Soerjono Soekanto, 'Kesadaran Hukum Dan KepatuhanHukum', Jurnal Hukum $\mathcal{E}$ Pembangunan, 7.6 (1977), 462-70. http://dx.doi.org/10.21143/jhp.vol7.no6.742

${ }^{18}$ Dina Siegel, 'Diamonds and Organized Crime: The Case of Antwerp', in Organized Crime: Culture, Markets and Policies, ed. by Dina Siegel and Hans Nelen, 1st edn (New York: Springer, 2008), pp. 85-96. https://doi.org/10.1007/978-0-387-74733

19 Siegel. https://doi.org/10.1007/978-0-387-74733

${ }^{20}$ Kathryn Gordon and Maiko Miyake, 'Business Approaches to Combating Bribery: A Study of Codes of Conduct', Journal of Business Ethics, 34.3 (2001), 161-73. Google Scholar
} 
Every position in the hierarchy and other positions with special functions are given on the basis of kinship relations, meetings, or rational considerations because of expertise. This position does not depend on someone who occupies it at a particular time because someone who is truly able to maintain the integrity of business activities and is actively trying to achieve goals will have a permanent position. After all, organized crime always tries to avoid competition by doing everything possible to become a monopoly in certain fields and areas. Organized crime is also straightforward to use violence or bribery to achieve its goals. The nature of membership is limited, although people who are not members of the group can be involved because of pressure. Organized crime has clear rules, both written and unwritten, which are generally enforced with certain sanctions, including killing. ${ }^{21}$

From all the definitions stated above, it can be concluded that organized crime is a business activity, either for production or distribution or both, for goods and/or services that are illegal, unlawful, and against the law. The forms can be in the form of gambling, prostitution, narcotics manufacture, narcotics distribution, stolen goods transactions, and others. One of the keywords is illegal business activities. The nature of organized crime is closed but has an organizational structure. In running the organization, violence is the most common way. According to law, for camouflage, organized crime also forms a legal business entity, but its function is to close illegal businesses against the law. Crime is a basic understanding of criminal law. Sudarto states that a criminal act is a juridical definition. It is different from the term crime or crime (crime or verbrechen or misdaad) or criminologically. While Moeljatno states the term "Criminal acts are prohibited by criminal law and are threatened with punishment, whoever violates the prohibition and is an anti-social act. ${ }^{22}$ According to Utrecht, a criminal event includes a legal act or neglect of its consequences (conditions caused by actions or neglect)..$^{23}$

Narcotics and dangerous drugs are addictive substances classified as prohibited items for consumption by anyone because they result in health problems. This type includes methamphetamine, ecstasy pills, marijuana, heroin, and other additives. Included in the narcotics crime is the act of planting, maintaining, having in stock, possessing, storing, or controlling narcotics; producing, processing, importing, exporting, offering, selling, buying, receiving, intermediary in buying and selling, and using drugs. There are two views in looking at the class of drug users. Juridically, they are equated as perpetrators of drug crimes, although the punishments are different. Whereas currently, there is a new paradigm that views drug users as victims of crime from a network of dealers who aim to seek material and other benefits. Adherents of this latter view are non-

\footnotetext{
${ }^{21}$ Gordon and Miyake. Google Scholar

22 S H Moeljatno, Asas-Asas Hukum Pidana, Rineka Cipta, Jakarta, 2002. Google Scholar

${ }^{23}$ Frances Kahn Zemans, 'Legal Mobilization: The Neglected Role of the Law in the Political System', American Political Science Review, 77.3 (1983), 690-703. https://doi.org/10.2307/1957268
} 
governmental organizations engaged in drug eradication and drug treatment. Name the groups that are members of the Geram (Anti-Mad Movement), the AntiDrugs Movement (Grenades), and Prof. Psychiatrist. Dr. Dadang Hawari.

If viewed as criminals, drug users must be equated with other actors such as dealers and dealers. Therefore, it must be punished. On the other hand, if it is considered a victim, the person concerned must be cured, such as admitted to a rehabilitation institution or a drug-dependent hospital. Therefore, it is necessary to observe whether there is discretion towards the victims of these drug crimes. Paying attention to this view will be known through research: how the Police treat drug users.

In the context of this thesis, the people who are in the jurisdiction of the West Jakarta Police do not suspect the activities carried out by the suspect. This is undoubtedly a factor inhibiting the handling of cases that occur; e) the human resource factor is the potential contained in humans to realize their role as adaptive and transformative social beings who can manage themselves and all the potentials contained in nature towards achieving the welfare of life in a balanced and sustainable order. HR is more understood as an integral part of the system that makes up an organization. Competence, as well as education, is vital to avoid the existence of law enforcement officers, in this case, the police who are involved in narcotics either as users, dealers, distributors, or even drug dealers; and f) the cultural factors of the community that used to hold an immediate sense of kinship have now shifted towards individualism. This indirectly affects law enforcement related to narcotics because people are indifferent in supervising the social environment to stay away from narcotics. While the factors that help the handling of narcotics crimes are legal existence, in this case, Law Number 35 of 2009 concerning Narcotics provides the legal basis to overcome and eradicate narcotics crimes. The law enforcement factors become the decisive help to reveal the narcotics cases. This law enforcement is seen from the ability of the members to handle a case. In addition to the legal substance and law enforcement, the existence of the precision program launched by the National Police Chief related to professional competencies plays a major role. The facilities and infrastructure also support the work of the West Jakarta Metro Police Narcotics Investigation Unit to uncover the crime.

\section{Conclusion}

The factors that hinder the handling of narcotics crimes are legal factors, in this case, Law Number 35 of 2009 concerning narcotics, where it can be concluded that narcotics are substances or drugs that are very important for treatment purposes but will cause problems if misused. Major ones when abused include dependence and altered consciousness. The factor of law enforcement officials, the National Police, and the National Narcotics Agency being given the authority to conduct investigations on narcotics abuse. However, it is undeniable that many law 
enforcement officers still use narcotics. This is one of the inhibiting factors for handling and overcoming narcotics in Indonesia. Law enforcement factors are significant in eradicating and handling narcotics cases. Law enforcement factors must be balanced with the competence, commitment, and professionalism of law enforcement officers in carrying out their duties following applicable regulations and the Promoter program launched by the National Police Chief; c) environmental factors cannot be ignored in the context of a narcotics crime. As described in the Map of the jurisdiction of the West Jakarta Metro Police, environmental factors significantly affect the circulation of narcotics of various types ranging from methamphetamine, marijuana, ecstasy, heroin in the jurisdiction. The vast and extensive environment and very open access to entry and exit create a significant obstacle considering that narcotics circulation is getting easier and faster; d) community factors can inhibit handling narcotics crime cases.

\section{References}

Adianto, Joko, Rossa Turpuk Gabe, Rini Kurniawati, and Suciyhuma Armenda, 'From Shelters for Numbers to Shelters for Welfare: Rectifying the Social Housing Provision Programme in Jakarta', Housing Policy Debate, 2021, 1-19. https://doi.org/10.1080/10511482.2021.1981423

Beletsky, Leo, Grace E Macalino, and Scott Burris, 'Attitudes of Police Officers towards Syringe Access, Occupational Needle-Sticks, and Drug Use: A Qualitative Study of One City Police Department in the United States', International Journal of Drug Policy, $16.4 \quad$ (2005), 267-74. https://doi.org/10.1016/j.drugpo.2005.01.009

Dandira, Martin, 'Involvement of Implementers: Missing Element in Strategy Formulation', Business Strategy Series, $12.1 \quad$ (2011), 30-34. https://doi.org/10.1108/17515631111100386

Duncan, David F, Thomas Nicholson, Patrick Clifford, Wesley Hawkins, and Rick Petosa, 'Harm Reduction: An Emerging New Paradigm for Drug Education', Journal of Drug Education, 24.4 (1994), 281-90. https://doi.org/10.2190/087GB4ET-08JY-T08Y

Emmers, Ralf, 'International Regime-Building in ASEAN: Cooperation Against the Illicit Trafficking and Abuse of Arugs', Contemporary Southeast Asia, 29.3 (2007), 506-25.

\section{Google Scholar}

Fathurrohman, and Gisela Bichler, 'Explaining the Positional Importance of Actors Involved in Trafficking Methamphetamine into Indonesia', Global Crime, 22.2 (2021), 93-122. https://doi.org/10.1080/17440572.2020.1819249

Gordon, Kathryn, and Maiko Miyake, 'Business Approaches to Combating Bribery: A Study of Codes of Conduct', Journal of Business Ethics, 34.3 (2001), 161-73. 
Google Scholar

Hanson, Glen, Peter Venturelli, and Annette Fleckenstein, Drugs and Society (Burlington: Jones \& Bartlett Publishers, 2011). Google Scholar

Jauch, Lawrence R, William F Glueck, and Richard N Osborn, 'Organizational Loyalty, Professional Commitment, and Academic Research Productivity', Academy of Management Journal, $21.1 \quad$ (1978), 84-92. https://doi.org/10.5465/255664

Jauch, Lawrence R, Richard N Osborn, and William F Glueck, 'Short Term Financial Success in Large Business Organizations: The Environment-Strategy Connection', Strategic Management Journal, $1.1 \quad$ (1980), 49-63. https://doi.org/10.1002/smj.4250010106

- - - 'Success in Large Business Organizations: The Environment-Strategy Connection', in Academy of Management Proceedings (Academy of Management Briarcliff Manor, NY 10510, 1977), MCMLXXVII, 113-17. https://doi.org/10.5465/ambpp.1977.4977072

Jenner, Matthew S, 'International Drug Trafficking: A Global Problem with a Domestic Solution', Indiana Journal of Global Legal Studies, 18.2 (2011), 901-27. https://doi.org/10.2979/indjglolegstu.18.2.901

Li, Yang, Sun Guohui, and Martin J Eppler, Making Strategy Work: A Literature Review on the Factors Influencing Strategy Implementation (Beijing: Università della Svizzera italiana, 2008). Google Scholar

Lyman, Michael D, Drugs in Society: Causes, Concepts, and Control, 7th edn (New York: Routledge, 2013). https://doi.org/10.4324/9781315721682

Moeljatno, S H, Asas-Asas Hukum Pidana, Rineka Cipta, Jakarta, 2002. Google Scholar Monib, Farid Ahamd, Jamaluddin Qanet, Mohammad Dawod Nabeel, and Redwanullah Abdi, 'Comparative Study of Strategic Management Schools (Prescriptive, Descriptive and Integrated)', Open Journal of Business and Management, 9.4 (2021), 1965-79. https://doi.org/10.4236/ojbm.2021.94106

Nitibaskara, Ronny, Tegakkan Hukum Gunakan Hukum, ed. by Chris Verdyansah, 2nd edn (Jakarta: Penerbit Buku Kompas, 2007). Google Scholar

Reichard, Rebecca J, and Stefanie K Johnson, 'Leader Self-Development as Organizational Strategy', The Leadership Quarterly, 22.1 (2011), 33-42. https://doi.org/10.1016/j.leaqua.2010.12.005

Siegel, Dina, 'Diamonds and Organized Crime: The Case of Antwerp', in Organized Crime: Culture, Markets and Policies, ed. by Dina Siegel and Hans Nelen, 1st edn (New York: Springer, 2008), pp. 85-96. https://doi.org/10.1007/978-0-387-74733-

Soekanto, Soerjono, 'Kesadaran Hukum Dan KepatuhanHukum', Jurnal Hukum $\mathcal{E}$ Pembangunan, 7.6 (1977), 462-70.

https://doi.org/http://dx.doi.org/10.21143/jhp.vol7.no6.742

Steiss, Alan W, Strategic Management for Public and Nonprofit Organizations, ed. by Alan W. Steiss, 1st edn (New: Routledge, 2019). https://doi.org/10.4324/9781482275865 
Wheelen, Thomas L, J David Hunger, Alan N Hoffman, and Charles E Bamford, Strategic Management and Business Policy, 14th edn (Pearson Boston, MA, 2017), LV.

Google Scholar

Winstock, Adam R, Kim Wolff, and John Ramsey, 'Ecstasy Pill Testing: Harm Minimization Gone Too Far?', Addiction, 96.8 (2001), 1139-48. https://doi.org/10.1046/j.1360-0443.2001.96811397.x

Zemans, Frances Kahn, 'Legal Mobilization: The Neglected Role of the Law in the Political System', American Political Science Review, 77.3 (1983), 690-703. https://doi.org/https://doi.org/10.2307/1957268 